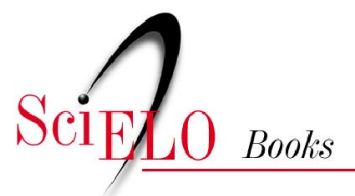

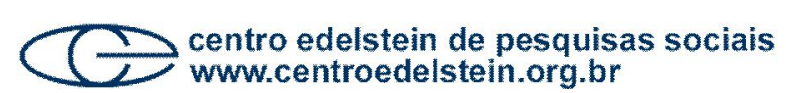

\section{France}

\author{
Daniel Thomas
}

THOMAS, D. France. In SORJ, B., CANTLEY, M., and SIMPSON, K., eds. Biotechnology in Europe and Latin America: prospects for co-operation [online]. Rio de Janeiro: Centro Edelstein de Pesquisas Sociais, 2010. pp. 46-52. ISBN: 978-85-7582-036-6. Available from SciELO Books $<\underline{\text { http://books.scielo.org }>\text {. }}$

\title{
(1) $(0)$
}

All the contents of this chapter, except where otherwise noted, is licensed under a Creative Commons Attribution-Non Commercial-ShareAlike 3.0 Unported.

Todo o conteúdo deste capítulo, exceto quando houver ressalva, é publicado sob a licença Creative Commons Atribuição Uso Não Comercial - Partilha nos Mesmos Termos 3.0 Não adaptada.

Todo el contenido de este capítulo, excepto donde se indique lo contrario, está bajo licencia de la licencia Creative Commons Reconocimento-NoComercial-CompartirIgual 3.0 Unported. 


\subsection{FranCE}

Daniel Thomas

\section{Introduction}

France has a long and distinguished history in the domain of biotechnology. The lasting legacy of Pasteur continues to be a world class centre of excellence in many areas of biotechnological relevance.

While the early history of biotechnology was distinguished the recent past has been less so. The Pasteur Institute represented the only focus of modern biotechnology in France. Many universities and industrial laboratories were working in relevant areas, but no overall aims or objectives integrated the obvious potential for excellence (Institut Pasteur excepted). Moved by the growing impact of the 'new biotechnology' of gene manipulation and monoclonal antibody production, France decided to assert its competence on the world stage. To a large extent this initiative was the result of President Mitterand's personal will to achieve French preeminence.

\section{The 'Programme Mobilisateur'}

Accordingly in 1982 the 'Programme Mobilisateur' was launched under the aegis of the Ministry of Technology, to cover a mobilisation in seven strategic areas of technology, including biotechnology. The original aim of the programme was to give France's biotechnology industry $10 \%$ of the world market by 1995. Spending in biotechnology by industry and government was quadrupled from about FF250 million in 1981 to FF1 billion in 1982.

Professor Daniel Thomas of the university of Compiègne was put in overall charge of the biotechnology programme. Provided with considerable means, both financial and political, the programme had an immediate rejuvenating and integrating effect on France's biotechnology endeavour. Special importance was given to the agriculture and agro-food sectors, vital for long term global strategies. Of great and lasting value has been the building of bridges between the industrial and academic research sectors. This process is gaining momentum. 
France has not failed to see the importance of international cooperation and the programme is specifically orientated to maximising the benefits obtainable from such collaboration. No fewer than 60 countries have sought French help in relevant areas of application and France has much to learn from EEC partners and the USA.

\section{PRIORITIES OF THE PROGRAMME MOBILISATEUR}

1. to assure logistical support for biotechnology

2. by consultation with the research administrations, CEA, CNRS, INSERM and INRA, involve the scientific community in determination of themes and priorities

3. intervene directly to initiate applied research projects that involve industrial/academic collaboration.

4. the provision of a training programme so as to meet the needs of a growing biotechnology industry

5. break down France's traditional isolation by forging international collaborations.

I. ELEMENTS OF LOGISTICAL SUPPORT

France is moving rapidly to establish the infrastructure necessary for a dynamic national biotechnology enterprise. Aspects of the infrastructure requirement include:

Establishment of competence in bioinformatics, to include nucleic acid sequence data banks, crystallographic data banks, Microbial data banks etc. There is a real need to develop a French competence in molecular graphics. In many cases existing European resources (EMBL for example) imply the formation of regional nodes and will offer valuable opportunities for French participation.

\section{THEMES AND PRIORITIES}

Five theme areas have been defined, including molecular biology, microbiology, enzymology/protein structure, plants and immunology.

Gene manipulation is but a means to an end and it should be made routinely available to all those with a requirement.
Microbial diversity presents a range of untapped potential. Classification and studies in microbial physiology and genetics hold out the prospect of valuable new products and processes. Anaerobes in particular have been largely ignored.

Enzymes/Protein structure. With the increased capability for tailoring genes, it is necessary to develop those tools which make protein engineering a possibility. X-Ray diffraction, molecular graphics, NMR determinations and the tools of molecular genetics form an integrated package for protein design and modification.

Plant molecular biology has been recognised as a weak link in the economic growth of biotechnology. France defined this priority area even before the EEC. Government institutes, especially INRA (Institut National pour la Recherche Agronomique) have international standing. The main requirement is increased manpower.

Immunology has been the key to dramatic changes in diagnosis. Monoclonal antibodies resulting from hybridoma technology have created a new industry in rapid diagnosis, from pregnancy to swine fever. French industry has moved fast to remain competitive, but investment in basic research and training is essential.

III. INITIATION OF PROJECTS

The first area for action is the agro-food sector and the six following projects have been designated as being of industrial priority. Research in these areas will have direct economic benefits to French competitiveness.

Identification and classification of micro-organisms, development of fast diagnostic tools.

Development of competence in mixed or sequential culture methodology in the dairy and brewing industries.

The optimisation of enzymes in media of economic importance: complex media, heterogeneous media, non-aqueous media.

Special emphasis on R\&D of milk related bacteria in all sectors of the French food industry.

Optimisation of fermentation processes, both traditional and modern. 
Improvements in the understanding and control of the vinification process. areas.

At the end of 1985 FF35 million had been set aside for these priority

The second area for action is health, where France has a number of internationally competitive companies. Priority is to be given to the early recognition of disease states. Biotechnology has enormous scope for applications in preventative medicine: vaccines, diagnostics etc. for both human and veterinary applications. The fate of proteins from expression, through extraction and purification in commercial cultures is a priority. This will be linked to structural studies.

\section{TRAINING}

Centres of excellence, 'Poles' in the French nomenclature will meet the training requirements of the scientists and engineers needed to steer France's biotechnology industry towards the future. Centres at Compiègne and Toulouse are being followed by several others.

\section{INTERNATIONAL COLLABORATION}

The 'Programme Mobilisateur' is committed to close collaboration with European initiatives such as the BAP and BRIDGE programmes of the EEC and the EUREKA programme. The contribution of industry to these collaborative ventures will be critical. The Versailles Summit in 1986 defined the need for an international biotechnology network. France already contributes to model structures such as EMBL (France contributes 22\% of operating funds).

France has recognised the potential of collaboration with Latin America. A French delegation visited Argentina in 1986 and Brazil in 1987. Mexico has an established collaboration with France in the field of fermentation in the solid phase. ORSTOM, concerned with French overseas relations with the 3rd world is concerned with the potential of biotechnology to add value to marginal agriculture.

\section{Public Institutions in Biotechnology}

France has an established tradition of excellence in many fields of fundamental and applied research. The 'Programme Mobilisateur' referred to above rectifies an omission in the case of biotechnology. The research organisations active in biotechnology include the following: Centre des Etudes Nucleaire, CEA; Centre National de la Recherche Scientifique, CNRS; Institute National de la Recherche Agronomique, INRA; Institut National de la Santé et de la Recherche Medicale, INSERM; Institut Pasteur and the universities.

All of these organisations now have a structure which permits academic-industrial technology transfer. The Pasteur Institute is now a hybrid organisation with commercial and basic research activities.

The CEA, rather like equivalent institutions in W Germany and the United Kingdom has peripheral, but significant interests in biotechnology. These range from the obvious association of radiolabelling and diagnostics, through to the development of an independent competence in much of the relevant molecular biology and immunology.

The CNRS is France's leading agency for the funding of fundamental research. It has many institutes and employs a large number of France's fundamental research workers. Increasingly the CNRS is responding to the call for more applied research trends. The CNRS has played a major role in developing molecular biology and immunology in France.

INRA has always had a strong commitment to applied agricultural research. In recent years it has made determined moves to be at the forefront of biotechnology. Research on animal vaccines and immunogenicity is world class. INRA has several exclusive licencing deals with French companies, particularly in the area of diagnostics development.

INSERM, with its responsibility for medical research has always had applied research as a major part of its portfolio of work. Immunology research is one of INSERM's foci of excellence. INSERM is moving towards a clearer interpretation of its role in a scientific climate that increasingly heeds the call of economic necessity. 
INSERM has close relations with the newly founded company Immunotech, which commercialises the results of research. This involves a far greater degree of communication with other institutions and industry. Other areas of activity include the development of new bioactive agents, lymphokines and artificial vaccines.

The Institut Pasteur has a purely commercial division, Pasteur Production, a classic example of government privatisation. It is responsible for vaccine production and therapeutics. Its cell culture facilities are outstanding as are the basic biology support services. Research in the government sponsored Institute proper is supported by a number of funding agencies and covers areas as diverse as chromosome structure, microbial physiology and AIDS. Government funds of FF100 million are targeted at the disease, much of the spending is on the Pasteur facilities, which have developed sensitive tests.

The universities also make a contribution to biotechnological research. The university of Compiègne and certain other facilities are developing strong industrial and institutional links.

\section{The Biotechnology Industry}

The French biotechnology industry is dominated by three large pharmaceutical companies, Rhône-Poulenc, Roussel-Uclaf and Sanofi with in addition a much less significant 'second division' including both agrofood and pharmaceutical companies such as Bertin, Mérieux, LafargeCoppée, Limagrain, Moet-Hennessey, Serono.

Unlike the USA France has not seen a wave of opportunistic start ups in biotechnology. There have however been a number of company launches from the public sector and from big industry. Companies such as Immunotech, Transia and Transgène would fall into this category. Transgéne is a start up funded by predominantly government originated funds. An increasing proportion of the ownership has been acquired by private investors. Transia is a genetic engineering company set up by a consortium of agro-food industry. Biosys is a university of Compiègne spin off in the immunoogicals area. Venture capital funded launches are few and include Clonatec.
A fourth category of biotechnology companies would be the large agro-food companies with a small activity in the field. Such companies are typified by Fromageries Bel, Moet Hennessey, Gervais-Danone.

The interest level and commitment to biotechnology varies from Sanofi's state of the art competence in rDNA and expression systems, to a straightforward requirement for better process control in the cheese industry. 